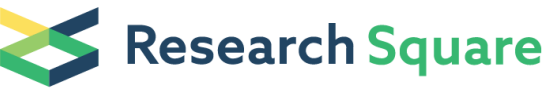 \\ Preprints are preliminary reports that have not undergone peer review. \\ They should not be considered conclusive, used to inform clinical practice, or referenced by the media as validated information.
}

\section{Divergent dimethylarginine dimethylaminohydrolase isoenzyme expression in the central nervous system}

\section{Alena A Kozlova}

Technische Universitat Dresden Medizinische Fakultat Carl Gustav Carus

\section{Vinitha N Ragavan}

Technische Universitat Dresden Medizinische Fakultat Carl Gustav Carus

\section{Natalia Jarzebska}

Technische Universitat Dresden: University Centre for Vascular Medicine and Department of Internal Medicine

\section{lana V Lukianova}

Technische Univeritat Dresden: University Hospital Carl Gustav Carus

\section{Anastasia E Bikmurzina}

Saint Petersburg State University: Department of general Physiology

\section{Elena Rubets}

Technische Universitat Dresden: University Centre for Vascular Medicine and Department of Internal Medicine

\section{Toshiko Suzuki-Yamamoto}

Okayma Prefectural University: Faculty of Health and Welfare Science

\section{Masumi Kimoto}

Okayma Prefectural University: Faculty of Health and Welfare Science

\section{Arduino A Mangoni}

Flinders University College of Medicine and Public Health

\section{Raul R Gainetdinov}

Saint-Petersburg State University: Institute of Translational Biomedicine and Saint-Petersburg University Hospital

\section{Norbert Weiss}

Technische Universitat Dresden: University Centre for Vascular Medicine and Department of Internal Medicine

\section{Michael Bauer}

Technische Universitat Dresden: University Hospital Carl Gustav Carus

\section{Alexander G Markov}

Saint-Petersburg State University: Department of General Physiology

\section{Roman N Rodionov}


Technische Universitat Dresden: University Centre for Vascular Medicine and Department of Internal Medicine

\section{Nadine Bernhardt ( $\nabla$ nadine.bernhardt@uniklinikum-dresden.de )}

Technische Universitat Dresden Medizinische Fakultat Carl Gustav Carus https://orcid.org/0000-00023188-8431

\section{Research Article}

Keywords: DDAH1, DDAH2, brain, mouse, human

Posted Date: March 19th, 2021

DOl: https://doi.org/10.21203/rs.3.rs-148653/v2

License: (c) (1) This work is licensed under a Creative Commons Attribution 4.0 International License. Read Full License 


\section{Abstract}

The endogenous methylated derivative of $L$-arginine, $N^{G}-N^{G}$-dimethyl- - -arginine (asymmetric dimethylarginine, ADMA), an independent risk factor in many diseases, inhibits the activity of nitric oxide synthases and, consequently, modulates the availability of nitric oxide. While most studies on the biological role of ADMA have focused on endothelial and inducible nitric oxide synthases modulation and its contribution to cardiovascular, metabolic, and renal diseases, a role in regulating neuronal nitric oxide synthases and pathologies of the central nervous system is less understood. The two isoforms of dimethylarginine dimethylaminohydrolase (DDAH), DDAH1 and DDAH2, are thought to be the main enzymes responsible for ADMA catabolism. A current impediment is the limited data on specific tissue and cellular distribution of DDAH enzymes within the brain. In this study, we provide a detailed characterization of the regional and cellular distribution of DDAH1 and DDAH2 proteins in adult murine and human brain. Immunohistochemical analysis showed a wide distribution of DDAH1, mapping to multiple cell types, while DDAH2 was detected in a limited number of brain regions and exclusively in neurons. Our results provide key information for the investigation of the pathophysiological roles of the ADMA/DDAH system in neuropsychiatric diseases and pave the way for the development of novel selective therapeutic approaches.

\section{Introduction}

Dimethylarginine dimethylaminohydrolases (DDAH) are a family of enzymes that metabolize methylated arginines. In mammals, there are two isoforms, DDAH1 and DDAH2, which have around $50 \%$ identity in their amino acid sequences (Frey et al, 2006) and differential tissue expression patterns (Leiper et al, 1999, Dayal et al, 2008). DDAH1 mRNA is widely expressed in mammals, particularly in the kidney, brain, and liver, while $D D A H 2$ mRNA is primarily found in the heart, lung, and placenta (Dayal et al, 2008, Leiper et al, 1999). DDAH1 was first discovered by Ogawa and colleagues who also identified that its catabolic reaction results in the formation of citrulline and dimethylamine (Ogawa et al, 1987). There are three forms of methylated arginine, which are formed ubiquitously through degradation of proteins (Kakimoto and Akazawa, 1970, McDermott, 1976), namely $N^{G}$-monomethyl-囚-arginine (ख-NMMA), $N^{G}-N^{G}$-dimethyl-囚arginine (asymmetric dimethylarginine, $A D M A$ ) and $N^{G}-N^{\prime}{ }^{G}$-dimethyl- $\rrbracket$-arginine (symmetric dimethylarginine, SDMA). However, only $\triangle-N M M A$ and ADMA are primarily hydrolysed by the DDAH enzymes while SDMA is mainly removed by renal excretion (Ogawa et al, 1989, McDermott, 1976, Leiper et al, 1999).

Research on DDAH has mostly focused on its role in metabolising ADMA, given that plasma concentrations of ADMA are higher than those of $\triangle-N M M A$ (Meyer et al, 1997). Moreover, ADMA is linked to various pathologies; with elevated ADMA concentration observed in endothelial dysfunction, chronic renal failure, hypertension, heart failure, diabetes, and atherosclerosis (Boger, 2005, Zoccali et al, 2001, Usui et al, 1998, Miyazaki et al, 1999, Leone et al, 1992, Vallance et al, 1992, Chen et al, 2012). ADMA is a potent inhibitor of nitric oxide synthases (NOSs), a family of enzymes responsible for the production of nitric oxide (NO). Thus, DDAH inhibition leads to increased ADMA concentrations and, consequently, 
reduced NO availability (MacAllister et al, 1996). Conversely, overexpression of DDAH1 results in reduced ADMA concentration and increased NO production (Ayling et al, 2006). Furthermore, ADMA causes uncoupling of NOS, a process that leads to production of superoxides (Toth et al, 2007, Antoniades et al, 2009).

NO is a gaseous signalling molecule that is involved in various biological processes including the modulation of central nervous system (CNS) functions (Calabrese et al, 2007). There are three variants of the NOS enzymes, neuronal NOS (nNOS), inducible NOS (iNOS) and endothelial NOS (eNOS). Within the CNS, nNOS and eNOS have been shown to regulate learning and memory formation, neurogenesis, and long-term synaptic transmission, while iNOS has an immunoregulatory function (Asif et al, 2013, Chen et al, 2005, Böhme et al, 1993, Hölscher et al, 1996, Son et al, 1996, Zhou et al, 2007, Sonar and Lal, 2019). Upregulation of nNOS and/or iNOS has been implicated in brain ischemia and the pathogenesis of neurodegenerative diseases such as Parkinson's disease and Alzheimer's disease (Zhou et al, 2007, Gatto et al, 2000, Izumi et al, 1992, Gang Zhang et al, 1994, Hannemann et al, 2020). Numerous studies have also demonstrated the key role of the nNOS-NO pathway in the aetiology of affective disorders such as depression (Selley, 2004, Baranyi et al, 2015, Ozden et al, 2020) and bipolar affective disorder (Sağlam Aykut et al, 2012, Ustundag et al, 2020). This suggests that the modulation of NOS activity may have therapeutic effects also in CNS disease states (reviewed in (Dhir and Kulkarni, 2011, Freudenberg et al, 2015)). As ADMA is the major endogenous inhibitor of NOS, targeting DDAH may represent a promising strategy for the development of new treatment approaches.

The function of DDAH isoforms in the brain however remains elusive. Assessing the pathophysiological role of DDAH in the brain requires in-depth knowledge of regional and cellular DDAH expression profiles to inform how modulation of DDAH will affect different brain regions or cellular subtypes. We sought to address this issue by providing a detailed mapping of DDAH1 and DDAH2 regional and cellular protein expression in the murine brain and a comparative analysis in human post-mortem tissue samples.

\section{Materials And Methods}

\section{Animals and tissue collection}

Experiments were conducted in 10 male C57BI/6J mice 10-12 weeks old purchased from the Jackson Laboratory, USA. Animals were housed in a 12-h light dark cycle (lights on at 06:00) with food and water ad libitum. All efforts were made to reduce animal suffering and number of animals used. Mice were deeply anesthetized with a mixture of $100 \mathrm{mg} / \mathrm{kg}$ ketamine and $10 \mathrm{mg} / \mathrm{kg}$ xylazine, transcardially perfused with phosphate buffered saline (PBS) followed by $4 \%$ paraformaldehyde (PFA). Brains were dissected and post-fixed in 4\% PFA overnight, cryoprotected in $20 \%$ sucrose in PBS up to four days, frozen in methylbutane at $-40^{\circ} \mathrm{C}$ and then stored at $-80^{\circ} \mathrm{C}$. Coronal or sagittal sections of $40 \mu \mathrm{m}$ thickness were cut on a freezing microtome (Leica CM1850) and stored in antifreeze (25\% glycerol, $25 \%$ ethylene glycol in PBS) at $-20^{\circ} \mathrm{C}$ until further processing.

\section{Human tissue collection}


Frontal gyrus samples from normal human brain tissue were obtained through the National Health and Medical Research Council South Australian Brain Bank. Brain samples were extracted and embedded in paraffin. Sample blocks were cut in $8 \mu \mathrm{m}$ sections and mounted onto gelatin-coated slides. Additional brain tissue samples were obtained from a 49-year-old man diagnosed with acute lymphoblastic leukemia obtained from N.N. Petrov National Medical Research Center of Oncology, Russia. Brain samples were extracted and dissected according to The Human Brain Atlas into prefrontal cortex and amygdala (The Human Brain, 2020). Samples were post-fixed in 10\% PFA for seven days and then cryoprotected in $15 \%$ sucrose in PBS up to 4 days. Sections of $35 \mu \mathrm{m}$ thickness were cut on a freezing microtome (Leica CM1850UV) and placed directly on glass slides.

\section{Immunohistochemical staining}

Brain sections were deparaffinised by incubation in xylene followed by washing with decreasing ethanol concentrations $(100 \%, 95 \%, 75 \%)$ for 5 min each. All further washing steps were performed in trisbuffered saline (TBS) with azide (TBS with $0,1 \%$ sodium azide). For elimination of endogenous peroxidase activity, slides were covered with $1 \% \mathrm{H} 202-50 \%$ methanol and placed in a humidified chamber for $10 \mathrm{~min}$. Then, sections were washed and blocked in $20 \%$ normal horse serum (NHS) in TBS-azide for 1 h. Slides were incubated overnight with primary antibodies solution (1\% NHS in TBS-azide). All antibodies and respective dilutions used are listed in Table 1. Sections were washed $3 \times 5$ min and incubated with biotin-conjugated secondary antibody solution (1\% NHS in TBS-azide). Sections were further washed $3 x$ 5 min and incubated with ABC-kit solution (Vector PK-4000, Vectastain) for $60 \mathrm{~min}$. Sections were again washed $3 \times 5 \mathrm{~min}$ and exposed to the DAB reaction (D4293, SigmaFast, dissolved in $5 \mathrm{ml}$ of TBS and 3.5 $\mathrm{Ll}_{\mathrm{H}} \mathrm{H}_{2}$ ). The reaction was stopped with TBS-azide. After brief washing, sections were counter-stained with hematoxylin, dehydrated (three washes $100 \%$ ethanol, two washes in xylene) and mounted with DPX (mixture of distyrene, a plasticizer, and xylene).

\section{Immunofluorescence}

Immunofluorescence staining on mouse samples was carried out on free-floating sections. For human samples, antigen retrieval was performed by boiling the slides in citrate buffer $(0.01 \mathrm{M}, \mathrm{pH} 6.0)$ for 10 min. Initial washing was performed $3 \times 15$ min in PBS followed by blocking in $10 \%$ normal donkey serum (NDS, ab7475, Abcam) and $0.2 \%$ Triton X-100 in PBS for $2 \mathrm{~h}$ at room temperature. Sections were then incubated overnight at $4^{\circ} \mathrm{C}$ in primary antibody solution (3\% NDS and $0.2 \%$ Triton X-100 in PBS). Sections were washed $3 \times 15$ min with PBS and incubated with fluorescence conjugated secondary antibody solution ( $3 \% \mathrm{NDS}$ and $0.2 \%$ Triton X-100 in PBS) for $2 \mathrm{~h}$ at room temperature. All antibodies tested are listed in Supplementary Table S1 and Table S2 while all antibodies used for the final study including the dilutions are listed in Table 1. Sections were then washed $3 \times 15 \mathrm{~min}$ in PBS and nuclei were counterstained for 10 min with 4',6-diamidino-2-phenylindole (DAPI) in PBS. After a final 10 min wash, sections were mounted on glass slides (SuperFrost Ultra Plus, Thermo Scientific) with Mowiol (MERCK, \#475904). For double staining, sections were incubated in mixed primary antibodies solutions. Samples were visualized and analysed using Zeiss Observer Z.1 (ApoTome II) widefield microscopy or Zeiss 
LSM880 confocal microscopy, using Zen 3.2 (blue edition) and ImageJ 1.50e software (Schneider et al, 2012).

\section{Results}

Comprehensive antibody validation experiments were carried out using western blot and cell and tissue immunostaining. This approach allowed analysis of various available antibodies against DDAH1 and DDAH2 in order to identify the most specific antibodies for the final study (Supplementary Table S1-S2, Supplementary Figure S1-S2). We focused on the molecular mass of the protein band and its intensity in addition to the specificity of antibody binding with endogenous DDAH1 and DDAH2.

\section{DDAH1 distribution in the mouse brain}

To investigate DDAH1 protein distribution in the brain, we initially used anti-DDAH1 staining on mouse brain sections. As shown in Fig. 1a, DDAH1 was widely distributed with an intense signal in the striatum, cortex and hippocampal formation (HPF). A moderate signal was observed in the thalamus and cerebellum (CB). In the striatal regions, cortex, HPF and CB the DDAH1 positive cells had an area of 12-16 $\mu \mathrm{m}^{2}$, star-shaped soma and many processes. In addition, a few cells with the same size but with a round soma and low expression level of DDAH1 were observed. Moreover, DDAH1 positive cells with starshaped morphology were detected in white matter structures such as corpus callosum. In the thalamus and in some structures of the midbrain and hindbrain, low levels of DDAH1 expression were observed in round-shaped cells with 16-18 $\mu \mathrm{m}^{2}$ area, which were slightly bigger than the cells in the HPF and striatum.

Within cortical regions, DDAH1 immunoreactivity was intense in layers I - IV and isocortex (Fig. 1a, box 1). In the striatum, cells with DDAH1 expression were evenly distributed. DDAH1 positive cells were detected in both the dorsal and ventral regions, in the lateral septal complex and, in a small amount, in the striatum-like amygdalar nuclei. The most intense DDAH1 expression, however, was observed in the dorsal region of the striatum (Fig. 1a, box 2). In the thalamus, the DDAH1 signal was moderate and present only in a limited number of brain nuclei such as the paraventricular nucleus (PVT) (Fig. 1a, box 3) and the reticular nucleus (RT). In HPF, few DDAH1 positive cells were present in Ammon's horn (cornu Ammonis, CA) and the dentate gyrus (DG). In the CA, DDAH1 positive cells were observed in the stratum oriens (so), stratum radialis (sr), and stratum lacunosum-moleculare (sIm) layers (Fig. 1a, box 4). In the DG, strong DDAH1 expression was present in the polymorph and molecular layers. Interestingly, no DDAH1 positive cells were found in both the pyramidal layer (sp) of CA and the granule cell layer in the DG. However, we observed some processes of DDAH1 positive cells that were passing through these layers. DDAH1 immunoreactivity was strong in different olfactory areas. High expression levels were observed in the main olfactory bulb (MOB), anterior olfactory nucleus (AON) and in the layer II of the piriform cortex (Fig, 1a, box 5). In CB, DDAH1 immunoreactivity was low in the Purkinje layer, without any detectable DDAH1 expression in other layers and cerebellar nuclei (Fig. 1c). Additionally, some DDAH1 positive cells were observed in the dorsal nucleus Raphe (Fig. 1b). 
We compared our findings to publicly available mRNA expression datasets (Allen Institute for Brain Science, 2010, Linnarsson Lab, 2020) observing similar and intense expression profiles in the cortex, CB and $\mathrm{MOB}$ as well as low expression in the hypothalamus. Further high levels of DDAH1 protein in the striatum and HPF mapped to low Ddah1 expression (Allen Institute for Brain Science, 2010). On the contrary, low IHC reactivity reflected intense Ddah1 expression in the ventral tegmental area. Notably, the strongest Ddah1 mRNA signals were found in a wide number of thalamic nuclei (Allen Institute for Brain Science, 2010) while we observed only moderate DDAH1 protein expression restricted to a small number of nuclei including the PVT and RT (see Supplementary Table S3).

\section{DDAH1 is expressed in both neuronal and glial cells}

Next, we determined specific cell type expression by co-labelling analysis of DDAH1 with neuronal marker (NeuN), glial fibrillary acidic protein (GFAP), oligodendrocyte transcription factor (Olig2), ionized calciumbinding adapter molecule 1 (Iba1) and platelet/endothelial cell adhesion molecule 1 (PECAM-1) (Fig. 2h). On the one hand, we found overlapping signal between the neuronal marker NeuN and DDAH1 in RT and PVT (Fig. 2a) but no overlap between DDAH1 and the astrocyte marker GFAP (Fig. 2d) On the other hand, DDAH1 and GFAP were expressed by the same cells in all layers of the HPF (Fig. 2c), but we did not observe any overlap between DDAH1 and NeuN (Fig. 2b). Immunocytochemical analysis on primary cell culture of cortical and hippocampal origin confirmed the presence of DDAH1 in astrocytes and neurons (Supplementary Methods, Figure S3a-c). Additionally, we performed co-staining for DDAH1 and other cell type markers such as Olig2 for oligodendrocytes, Iba1 for microglia and PECAM-1 for endothelial cells. We observed partial co-labelling between DDAH1 and PECAM-1 throughout the brain, however the majority of PECAM-1 did not overlap with DDAH1 (Fig. 2e). Despite prevalent Iba1 expression, e.g., within the striatum, we did not detect any co-labelling with DDAH1 (Fig. 2f). Furthermore, no co-labelling between DDAH1 and Olig2 was found (Fig. $2 \mathrm{~g}$ ). In summary, we found that DDAH1 is widely distributed in the rodent brain and expressed in a region specific manner in both neuronal and astrocyte cells as well as within the endothelium of the vascular structures.

\section{DDAH2 protein is expressed in a limited number of brain regions}

To build a map of DDAH2 protein expression, we firstly investigated its distribution on consecutive coronal mouse brain sections. As shown in Fig. 3a, DDAH2 immunoreactivity was detected in a limited number of brain structures. We found high expression levels in the cortex, HPF, striatum, and pallidum. Low expression was observed in the cortical subplate. In all structures, DDAH2 positive cells had a round shaped soma, an area of $15-19 \mu \mathrm{m}^{2}$ and stained processes.

Within the striatum, intense DDAH2 staining was observed in the ventral region, the lateral septal complex and the striatum-like amygdalar nuclei but not in the dorsal part. DDAH2 positive cells were observed in the lateral septal nucleus (LSN) (Fig. 3d) of the lateral septal complex. Here, DDAH2 signal was detected in the caudal part of LSN, while no staining was apparent in the rostral and ventral parts. In the ventral striatum, DDAH2 positive cells were found in the fundus of the striatum (FS) (Fig. 3e) and the olfactory 
tubercle (OT) (Fig. 3b). DDAH2 immunoreactivity was also observed within the nucleus accumbens. In the striatum-like amygdalar nucleus, intense DDAH2 expression was found in the central amygdalar nuclei (CEA) (Fig. 3a, box 2), without staining in other nuclei such as the anterior or medial amygdalar nucleus. In the pallidum, DDAH2 staining was observed in the caudal part in the bed nuclei of the stria terminalis (BST) (Fig. 3c). There was no DDAH2 fluorescence signal in other regions of the pallidum. Within the cortical regions, DDAH2 immunoreactivity was restricted to layer II of the piriform cortex (Fig. 3a, box. 3) and layer II of the entorhinal area. Low DDAH2 expression was detected in the layer II of the auditory area, somatosensory, orbital, prelimbic, infralimbic and posterior parietal association areas in the cortex. Further, we observed region specific DDAH2 expression in the HPF restricted to the pyramidal layer of CA1 while no signal was observed in CA2 and CA3 (Fig. 3a, box 1). Additionally, intense DDAH2 expression was observed in the subiculum and the presubiculum. Finally, within the cortical subplate, DDAH2 positive cells were restricted to the endopiriform nucleus.

Again, we compared our findings to the publicly available mRNA expression datasets (Allen Institute for Brain Science, 2010, Linnarsson Lab, 2020). Ddah2 mRNA signals in the cortex, in olfactory areas and in the HPF, matched our protein expression data (refer to Table S4). However, there were differences in Ddah2 mRNA distribution within the sub-regions of the HPF documented by the Allen Institute for Brain Science (Allen Institute for Brain Science, 2010) and our data. According to the published data, Ddah2 mRNA can be identified in CA1, CA2 and CA3, whereas Ddah2 protein signal in our study was restricted to CA1. Striatal protein expression was found but could not be compared in detail due to the limited sagittal data availability on the Allen Mouse Brain Atlas (Allen Institute for Brain Science, 2010). Finally, Ddah2 mRNA expression in the HPF, striatum, and hypothalamus was confirmed in our protein assessment in accordance with the known Ddah2 mRNA distribution available at the Mouse Brain Atlas (Linnarsson Lab, 2020).

\section{DDAH2 is expressed exclusively within neurons}

Based on the already obtained cell size and shape information we performed co-labelling analysis with the neuronal marker NeuN. We found a complete overlap of DDAH2 positive cells with NeuN in all structures (Fig. 4). DDAH2/NeuN expression was observed in CA1, while NeuN immunoreactivity continued in CA2 and CA3 (Fig. 4a). The neuronal origin of DDAH2 positive cells was also confirmed for layer II of the piriform cortex while NeuN positive cells in both layers I and III did not express DDAH2 (Fig. 4b). The CEA showed specific DDAH2 and NeuN positive staining, which was not observed in other amygdalar nuclei (Fig. 4c). Intense DDAH2 and NeuN positive expression was seen in the caudal part of the LSN (Fig. 4d). For validation, we also performed analysis of DDAH2 and GFAP double staining, which as expected did not yield any co-labelling (Fig. 4e). Similarly, PECAM-1 positive endothelial did not display DDAH2 signal (Fig. 4f). Results of immunocytochemical analysis on early postnatal primary cell culture of cortical and hippocampal origin confirmed the presence of DDAH2 in neurons; however, a minor fraction of DDAH2 positive cells also stained for GFAP (Figure S3d-f). In summary, within the adult mouse brain DDAH2 protein was found to be expressed exclusively in neuronal cells within a limited number of brain structures. 


\section{DDAH1 and DDAH2 are expressed by different cell populations}

Next, we performed co-labelling experiments of DDAH1 and DDAH2. As shown in Fig. 5, both DDAH1 and DDAH2 signal were observed in the HPF, cortex and striatum. However, DDAH1 and DDAH2 were consistently expressed by different cells. In the HPF, DDAH2 was present only in neurons of $s p$ of CA1 whereas DDAH1 positive cells were observed in astrocytes in other layers (so, sr, slm) (Fig. 5c). In the striatum, DDAH2 was expressed by neurons in a few striatal structures such as LSN, whereas DDAH1 was broadly present in astrocytes (Fig. 5b). Additionally, DDAH2 and DDAH1 expression was observed in the BST (Fig. 5b) and entorhinal cortex but did not show cellular overlap Fig. 5d. In summary, our results suggest that DDAH1 and DDAH2 protein are detected in the same regions of the brain but always in a cell type restricted manner.

\section{Identical cell types in mouse and human brain tissue express DDAH1 and DDAH2}

Finally, we performed comparative analysis in human and murine tissue. We established staining of DDAH1 and DDAH2 on human post-mortem tissue to compare its distribution with our murine data (Fig. 6). At first, we performed $D A B$ staining in tissue samples from the medial frontal gyrus, where both DDAH1 (Figs. 6a,b) and DDAH2 (Figs. 6e,f) signals were observed. DDAH1 positive cells appeared small (app. $15 \mu \mathrm{m}^{2}$ ) and star-shaped with multiple processes reminiscent of astrocytes, whilst DDAH2 positive cells had neuronal features and an area of app. $19 \mu \mathrm{m}^{2}$. Comparable findings are derived from DDAH1 expression in mouse (Fig. 6d) and human cortex (Fig. 6c) as well as DDAH2 staining on mouse (Fig. 6h) and human (Fig. $6 \mathrm{~g}$ ) amygdala. In summary, similar cell types express DDAH1 and DDAH2 in both human and mouse CNS tissue.

\section{Discussion}

The main findings of our study are that: 1) DDAH1 is broadly distributed in the adult mouse brain; 2 ) DDAH1 is expressed in both neuronal and astrocyte cells as well as within the endothelia of the vascular structures; 3) DDAH2 is expressed exclusively in neuronal cells within a limited number of brain structures; 4) DDAH1 and DDAH2 can be expressed in the same brain region but not within the same cell; 5) The distribution pattern of DDAH1 and DDAH2 in the brain is similar in mice and humans.

Previous studies on murine DDAH1 protein expression have been sparse. In line with our histochemical results, a strong DDAH1 expression was observed in whole brain homogenate (Hu et al, 2011) and regional expression was reported for the hippocampus, dorsal root ganglia and spinal cord (D'Mello et al, 2015). Also, DDAH1 protein was detected in a primary cell culture with cortical origin (Dowsett et al, 2015). Further support for our findings comes from databases reporting wide Ddah 1 mRNA distribution throughout the mouse brain and for distinct cell types (Linnarsson Lab, 2020, Allen Institute for Brain Science, 2010). Our findings confirmed the expression of DDAH1 in neurons and astrocytes but not in oligodendrocytes, and low expression in endothelial cells. Nevertheless, the regional distribution of DDAH1 protein in the mouse brain is more limited compared to the database mRNA expression profile. 
The discrepancy may be explained by post-transcriptional and post-translational regulation in addition to differences in stability of both mRNA and protein (de Sousa Abreu et al, 2009). Another technical issue could be the use of antibodies. Although specificity was tested prior to application, sensitivity could be a limiting factor for the detection of low protein expression levels.

Likewise, an early study in human tissue samples from various organs showed strong DDAH1 mRNA expression in the brain (Leiper et al, 1999), which was later confirmed by the Human Protein Atlas and the HGNC database (EMBL-EBI, 2020, Human Protein Atlas, 2020, Uhlén et al, 2015). Additionally, mRNA dot blot analysis using isoform-specific cDNA probes showed DDAH1 expression in the amygdala, striatum, cerebellum, thalamus, hippocampus and various cortical areas (Tran et al, 2000). Besides acknowledging the wide mRNA expression in all brain regions tested, protein expression was found to be limited to the cerebral cortex, hippocampus, basal ganglia and cerebellum (Uhlén et al, 2015, Human Protein Atlas, 2020). Prior studies in combination with our data therefore indicate similar expression profiles between human and murine datasets on both the mRNA and protein level.

Our study revealed a sparser distribution of DDAH2, compared to the widely represented DDAH1, in agreement with western blot analyses showing significantly lower expression of DDAH2 than DDAH1 in murine whole brain samples (Hu et al, 2011). Regional DDAH2 protein expression profile was limited to the cortex, hippocampus, striatum, and pallidum. This profile partially correlated with available mRNA expression data, which also included expression in the hypothalamus and cerebellum (Mouse ENCODE Consortium, 2019, Stamatoyannopoulos et al, 2012, Linnarsson Lab, 2020, Allen Institute for Brain Science, 2010). Similarly, very low DDAH2 mRNA distribution was detected in the human brain (Leiper et al, 1999) or found to be mostly restricted to the medulla and spinal cord (Tran et al, 2000). These findings were again confirmed by mRNA datasets, where $D D A H 2$ mRNA distribution in human brain tissue was barely present compared to the high level of expression observed in the other tissues, e.g., lung and foetal tissue (EMBL-EBI, 2020, Human Protein Atlas, 2020, Uhlén et al, 2015).

Additionally, we demonstrated for the first time that DDAH2 protein in the adult murine brain is found exclusively in neuronal cell types, which is in line with reported neuronal Ddah2 mRNA expression (Allen Institute for Brain Science, 2010, Linnarsson Lab, 2020). The neuronal identity of DDAH2 positive cells was also confirmed in our immunocytochemical analysis on primary cell cultures of cortical and hippocampal origin. However, in primary cell culture DDAH2 was additionally observed in astrocytes. The early postnatal origin of these samples and previous reports of high embryonic DDAH2 expression, which was found to decrease over development (Tran et al, 2000), may explain this finding. Of note, DDAH1 expression remains much more stable during development (Tran et al, 2000).

Taken together, our data indicate a distinct expression of DDAH isoforms in the brain. Such isolated pattern of expression of DDAH isoforms has also been observed in peripheral tissues. In the kidney, for example, DDAH1 is observed in the proximal tubules, while DDAH2 is expressed in the glomeruli, afferent arterioles, macula densa, and distal nephron, where each DDAH isoform has been found to regulate local ADMA concentrations in specific pathophysiologic processes (Onozato et al, 2008, Tomlinson et al, 
2015). Observed regional and cellular specific expression profiles of DDAH1 and DDAH2 thus support our hypothesis of different functions or divergent influences on brain activity. Early studies already suggested that $D D A H 1$ is primarily co-expressed with $n N O S$ in the brain and $D D A H 2$ is detected in tissues that also express eNOS and $i N O S$ such as endothelial tissue and immune cells respectively (Tran et al, 2000, Leiper et al, 1999, Suzuki-Yamamoto et al, 2012). Later it was shown that the DDAH1 expression patterns were completely different from nNOS expression patterns in rat and chicken during embryonic development (Mishima et al, 2004). Our study demonstrates that at least in the adult brain it is DDAH2, rather than DDAH1, which is neuron specific. By itself, this does not imply nNOS co-expression and further analyses need to be performed for clarification. Additionally, it is possible that the different expression patterns of DDAH isoforms are caused by different regulatory mechanisms and maybe even different substrate preferences of these enzymes (Todd et al, 2001, Nguyen Ba et al, 2014). Indeed, while the major role of DDAH1 in regulation of ADMA homeostasis is generally accepted, the relative contribution of DDAH2 towards ADMA clearance is still controversial (Wojciak-Stothard et al, 2007, Hasegawa et al, 2007, Hu et al, 2011, Wang et al, 2007).

Alterations in DDAH activity in the human brain may contribute to the development of certain neuropsychiatric disorders. Changes in the ADMA/NOS/NO pathway have been observed in patients with depression (Baranyi et al, 2015, Selley, 2004), bipolar affective disorder (Sağlam Aykut et al, 2012), migraine (Greco et al, 2015), schizophrenia (Celik et al, 2011), Parkinson's disease (Kirbas et al, 2016), and Alzheimer's disease (Selley, 2003). At the same time, there have been only limited advances in the diagnosis and treatment of these disorders in recent decades. Current therapies, mostly in the form of psychopharmacological agents, often lead to insufficient symptom relief and side effects. Thus, there is a need to develop new and targeted treatment strategies that specifically address the pathological processes from which symptoms arise. The described regional and cellular expression pattern of DDAH isoforms may facilitate the identification of specific pathophysiological roles played by these enzymes in the brain.

Further detailed investigations of DDAH isoform mutant mouse models may not only help to understand the functions of the DDAH/ADMA/NO pathway in the brain but also lead to the strategy of isoform specific modulation of DDAH activity as a potential new therapeutic target for psychiatric disorders.

\section{Declarations}

\section{Funding}

This work was supported through the woman habilitation promotion initiative from the Medical Faculty awarded to NB. -AAK received research scholarships from the German Academic Exchange Service and the Gesellschaft von Freunden und Förderern der TU Dresden. Further AAK and RRG received support through the project ID: 51143531 of the St. Petersburg State University, St. Petersburg, Russia. RNR was supported by funding from the German Heart Foundation/German Foundation of Heart Research $\mathrm{F} / 24 / 17$. 


\section{Competing interests}

The authors declare that they have no conflicts of interest.

\section{Availability of data and materials}

The data used and analysed are available from the corresponding author on reasonable request.

\section{Code availability}

Not applicable

\section{Author's contributions}

Alena A. Kozlova performed experiments on mouse and human tissue, conducted data analysis and interpretation. Vinitha N. Ragavan and Elena Rubets performed experiments on peripheral cell lines and antibody validation. lana V. Lukianova performed experiments on mouse brain primary cell cultures. Anastasia E. Bikmurzina, Alexander G. Markov and Arduino A. Mangoni contributed to human tissue experiments, analysis, and data interpretation. Nadine Bernhardt conceived the study and designed experiments. Roman N. Rodionov designed experiments and with Raul R. Gainetdinov, Michael Bauer, Norbert Weiss, Toshiko Suzuki-Yamamoto, Masumi Kimoto provided supervision and data interpretation. Alena A. Kozlova, Vinitha N. Ragavan, Natalia Jarzebska and Nadine Bernhardt wrote the manuscript. All authors carefully revised the first draft and read and approved the final version.

\section{Ethics approval}

Animal experiments were carried out in accordance to the European Communities Council Directive of 22nd September 2010 (2010/63/EU) under protocols approved by the animal ethics committees of the Technische Universität Dresden and the Landesdirektion Sachsen (ID TVV5/2019).

\section{Consent to participate}

Human tissue analysis was carried out in accordance with the St. Petersburg University Ethics Committee and the Southern Adelaide Health Service / Flinders University Human Research Ethics Committee (Project ID: 181/067).

\section{Consent for publication}

Not applicable.

\section{Acknowledgements}

We thank Ekaterina S. Karetnikova, Kristin Wogan and the Core Facility Cellular Imaging (TU Dresden) for their excellent technical support. We are grateful to Anna S. Artemyeva and the St. Petersburg State University Research Park "Chromas" (Human tissue collection) for human tissue sampling and the 
technical support of the experiments. Further, we acknowledge Prof. Georg Breier and Anke Klawitter for providing antibody and Dr. Eva Szego and Prof. Björn Falkenburger for providing primary cell culture samples.

\section{References}

Allen Institute for Brain Science (2010) Allen Mouse Brain Atlas. http://mouse.brain-map.org/ March 12, 2020.

Antoniades C, Shirodaria C, Leeson P, Antonopoulos A, Warrick N, Van-Assche T, Cunnington C, Tousoulis D, Pillai R, Ratnatunga C, et al (2009) Association of plasma asymmetrical dimethylarginine (ADMA) with elevated vascular superoxide production and endothelial nitric oxide synthase uncoupling: implications for endothelial function in human atherosclerosis. European Heart Journal 30: 1142-1150. https://doi.org/10.1093/eurheartj/ehp061

Asif M, Soiza RL, McEvoy M, Mangoni AA (2013) Asymmetric dimethylarginine: a possible link between vascular disease and dementia. Curr Alzheimer Res 10: 347-56.

https://doi.org/10.2174/1567205011310040001

Ayling LJ, Whitley GSJ, Aplin JD, Cartwright JE (2006) Dimethylarginine dimethylaminohydrolase (DDAH) regulates trophoblast invasion and motility through effects on nitric oxide. Human Reproduction 21: 2530-2537. https://doi.org/10.1093/humrep/del111

Baranyi A, Amouzadeh-Ghadikolai O, Rothenhäusler H-B, Theokas S, Robier C, Baranyi M, Koppitz M, Reicht G, Hlade P, Meinitzer A (2015) Nitric Oxide-Related Biological Pathways in Patients with Major Depression. PloS one 10: e0143397-e0143397. https://doi.org/10.1371/journal.pone.0143397

Boger RH (2005) Asymmetric dimethylarginine (ADMA) and cardiovascular disease: insights from prospective clinical trials. Vasc Med 10 Suppl 1: S19-25.

Böhme GA, Bon C, Lemaire M, Reibaud M, Piot O, Stutzmann J-M, Doble A, Blanchard J-C (1993) Altered synaptic plasticity and memory formation in nitric oxide synthase inhibitor-treated rats. Proceedings of the National Academy of Sciences 90: 9191-9194.

Calabrese V, Mancuso C, Calvani M, Rizzarelli E, Butterfield DA, Stella AM (2007) Nitric oxide in the central nervous system: neuroprotection versus neurotoxicity. Nat Rev Neurosci 8: 766-75.

https://doi.org/10.1038/nrn2214

Celik C, Cayci T, Ozdemir B, Akgul EO, Zincir S, Balikci A, Uzun O, Yaman H (2011) Plasma asymmetric dimethylarginine (ADMA) concentrations in patients with first and multiple episode schizophrenia. Psychiatry research 190: 177-180. https://doi.org/10.1016/j.psychres.2011.06.003 
Chen J, Zacharek A, Zhang C, Jiang H, Li Y, Roberts C, Lu M, Kapke A, Chopp M (2005) Endothelial nitric oxide synthase regulates brain-derived neurotrophic factor expression and neurogenesis after stroke in mice. The Journal of neuroscience : the official journal of the Society for Neuroscience 25: 2366-2375. https://doi.org/10.1523/JNEUROSCI.5071-04.2005

Chen S, Li N, Deb-Chatterji M, Dong Q, Kielstein JT, Weissenborn K, Worthmann H (2012) Asymmetric Dimethyarginine as Marker and Mediator in Ischemic Stroke. International Journal of Molecular Sciences 13: $15983-16004$.

Dayal S, Rodionov RN, Arning E, Bottiglieri T, Kimoto M, Murry DJ, Cooke JP, Faraci FM, Lentz SR (2008) Tissue-specific downregulation of dimethylarginine dimethylaminohydrolase in hyperhomocysteinemia. American journal of physiology. Heart and circulatory physiology 295: H816-H825.

https://doi.org/10.1152/ajpheart.01348.2007

de Sousa Abreu R, Penalva LO, Marcotte EM, Vogel C (2009) Global signatures of protein and mRNA expression levels. Mol Biosyst 5: 1512-26. https://doi.org/10.1039/b908315d

Dhir A, Kulkarni SK (2011) Nitric oxide and major depression. Nitric Oxide 24: 125-31. https://doi.org/10.1016/j.niox.2011.02.002

D'Mello R, Sand CA, Pezet S, Leiper JM, Gaurilcikaite E, McMahon SB, Dickenson AH, Nandi M (2015) Dimethylarginine dimethylaminohydrolase 1 is involved in spinal nociceptive plasticity. Pain 156: 20522060. https://doi.org/10.1097/j.pain.0000000000000269

Dowsett L, Piper S, Slaviero A, Dufton N, Wang Z, Boruc O, Delahaye M, Colman L, Kalk E, Tomlinson J, et al (2015) Endothelial Dimethylarginine Dimethylaminohydrolase 1 Is an Important Regulator of Angiogenesis but Does Not Regulate Vascular Reactivity or Hemodynamic Homeostasis. Circulation 131: 2217-2225. https://doi.org/10.1161/CIRCULATIONAHA.114.015064

EMBL-EBI (2020) HUGO Gene Nomenclature Commitee. https://www.genenames.org/ September 9, 2020.

Freudenberg F, Alttoa A, Reif A (2015) Neuronal nitric oxide synthase (NOS1) and its adaptor, NOS1AP, as a genetic risk factors for psychiatric disorders. Genes Brain Behav 14: 46-63.

https://doi.org/10.1111/gbb.12193

Frey D, Braun O, Briand C, Vašák M, Grütter MG (2006) Structure of the Mammalian NOS Regulator Dimethylarginine Dimethylaminohydrolase: A Basis for the Design of Specific Inhibitors. Structure 14: 901-911. https://doi.org/10.1016/j.str.2006.03.006

Gang Zhang Z, Chopp M, Gautman S, Zaloga C, Lan Zhang R, Schmidt HHHW, Pollack JS, Förstermann U (1994) Upregulation of neuronal nitric oxide synthase and mRNA, and selective sparing of nitric oxide synthase-containing neurons after local cerebral ischemia in rat. Brain Research 654: 85-95. https://doi.org/10.1016/0006-8993(94)91574-1 
Gatto EM, Riobó NA, Carreras MC, Cherñavsky A, Rubio A, Satz ML, Poderoso JJ (2000) Overexpression of Neutrophil Neuronal Nitric Oxide Synthase in Parkinson's Disease. Nitric Oxide 4: 534-539. https://doi.org/10.1006/niox.2000.0288

Greco R, Ferrigno A, Demartini C, Zanaboni A, Mangione AS, Blandini F, Nappi G, Vairetti M, Tassorelli C (2015) Evaluation of ADMA-DDAH-NOS axis in specific brain areas following nitroglycerin administration: study in an animal model of migraine. J Headache Pain 16: 560. https://doi.org/10.1186/s10194-0150560-2

Hannemann J, Appel D, Seeberger-Steinmeister M, Brüning T, Zummack J, Böger R (2020) Sequence Variation in the DDAH1 Gene Predisposes for Delayed Cerebral Ischemia in Subarachnoidal Hemorrhage. Journal of Clinical Medicine 9: 3900.

Hasegawa K, Wakino S, Tatematsu S, Yoshioka K, Homma K, Sugano N, Kimoto M, Hayashi K, Itoh H (2007) Role of asymmetric dimethylarginine in vascular injury in transgenic mice overexpressing dimethylarginie dimethylaminohydrolase 2. Circulation Research 101: e2-e10. https://doi.org/10.1161/circresaha.107.156901

Hölscher C, McGlinchey L, Anwyl R, Rowan MJ (1996) 7-Nitro indazole, a selective neuronal nitric oxide synthase inhibitor in vivo, impairs spatial learning in the rat. Learning \& Memory 2: 267-278.

Hu X, Atzler D, Xu X, Zhang P, Guo H, Lu Z, Fassett J, Schwedhelm E, Boger RH, Bache RJ, et al (2011) Dimethylarginine dimethylaminohydrolase- 1 is the critical enzyme for degrading the cardiovascular risk factor asymmetrical dimethylarginine. Arterioscler Thromb Vasc Biol 31: 1540-6.

https://doi.org/10.1161/atvbaha.110.222638

Human Protein Atlas (2020) Human Protein Atlas. http://www.proteinatlas.org September 9, 2020.

Izumi Y, Clifford D, Zorumski C (1992) Inhibition of long-term potentiation by NMDA-mediated nitric oxide release. Science 257: 1273-1276. https://doi.org/10.1126/science.1519065

Kakimoto Y, Akazawa S (1970) Isolation and Identification of $\mathrm{Ng}, \mathrm{Ng}$ - and $\mathrm{Ng}, \mathrm{N}$ 'g-Dimethylarginine, $\mathrm{N} \varepsilon$ Mono-, Di-, and Trimethyllysine, and Glucosylgalactosyl- and Galactosyl-ס-hydroxylysine from Human Urine. Journal of Biological Chemistry 245: 5751-5758.

Kirbas S, Kirbas A, Tufekci A, Cumhur Cure M, Cakmak S, Yazici T, Cure E (2016) Serum levels of homocysteine, asymmetric dimethylarginine and nitric oxide in patients with Parkinson's disease. Acta Clinica Belgica 71: 71-75. https://doi.org/10.1080/17843286.2016.1138592

Leiper JM, Santa Maria J, Chubb A, MacAllister RJ, Charles IG, Whitley GS, Vallance P (1999) Identification of two human dimethylarginine dimethylaminohydrolases with distinct tissue distributions and homology with microbial arginine deiminases. Biochem J 343 Pt 1: 209-14. 
Leone A, Moncada S, Vallance P, Calver A, Collier J (1992) Accumulation of an endogenous inhibitor of nitric oxide synthesis in chronic renal failure. The Lancet 339: 572-575. https://doi.org/10.1016/01406736(92)90865-Z

Linnarsson Lab (2020) Mouse Brain Atlas. http://mousebrain.org/ March 22, 2020.

MacAllister RJ, Parry H, Kimoto M, Ogawa T, Russell RJ, Hodson H, Whitley GS, Vallance P (1996) Regulation of nitric oxide synthesis by dimethylarginine dimethylaminohydrolase. Br J Pharmacol 119: 1533-40. https://doi.org/10.1111/j.1476-5381.1996.tb16069.x

McDermott JR (1976) Studies on the catabolism of Ng-methylarginine, $\mathrm{Ng}, \mathrm{Ng}$-dimethylarginine and $\mathrm{Ng}$, Ng-dimethylarginine in the rabbit. The Biochemical journal 154: 179-184.

https://doi.org/10.1042/bj1540179

Meyer J, Richter N, Hecker M (1997) High-Performance Liquid Chromatographic Determination of Nitric Oxide Synthase-Related Arginine Derivativesin Vitroandin Vivo. Analytical Biochemistry 247: 11-16. https://doi.org/10.1006/abio.1997.2008

Mishima T, Hamada T, Ui-Tei K, Takahashi F, Miyata Y, Imaki J, Suzuki H, Yamashita K (2004) Expression of DDAH1 in chick and rat embryos. Brain Res Dev Brain Res 148: 223-32.

https://doi.org/10.1016/j.devbrainres.2003.09.021

Miyazaki H, Matsuoka H, Cooke JP, Usui M, Ueda S, Okuda S, Imaizumi T (1999) Endogenous nitric oxide synthase inhibitor: a novel marker of atherosclerosis. Circulation 99: 1141-6.

https://doi.org/10.1161/01.cir.99.9.1141

Mouse ENCODE Consortium (2019) Mouse ENCODE Project. http://www.mouseencode.org March 22, 2020.

Nguyen Ba AN, Strome B, Hua JJ, Desmond J, Gagnon-Arsenault I, Weiss EL, Landry CR, Moses AM (2014) Detecting functional divergence after gene duplication through evolutionary changes in posttranslational regulatory sequences. PLOS Computational Biology 10: e1003977. https://doi.org/10.1371/journal.pcbi.1003977

Ogawa T, Kimoto M, Sasaoka K (1987) Occurrence of a new enzyme catalyzing the direct conversion of NG,NG-dimethyl-L-arginine to L-citrulline in rats. Biochem Biophys Res Commun 148: 671-7. https://doi.org/10.1016/0006-291x(87)90929-6

Ogawa T, Kimoto M, Sasaoka K (1989) Purification and properties of a new enzyme, NG,NGdimethylarginine dimethylaminohydrolase, from rat kidney. J Biol Chem 264: 10205-9.

Onozato ML, Tojo A, Leiper J, Fujita T, Palm F, Wilcox CS (2008) Expression of NG, NG-Dimethylarginine Dimethylaminohydrolase and Protein Arginine N-Methyltransferase Isoforms in Diabetic Rat Kidney: Effects of Angiotensin II Receptor Blockers. Diabetes 57: 172-180. https://doi.org/10.2337/db06-1772 
Ozden A, Angelos H, Feyza A, Elizabeth W, John P (2020) Altered plasma levels of arginine metabolites in depression. J Psychiatr Res 120: 21-28. https://doi.org/10.1016/j.jpsychires.2019.10.004

Sağlam Aykut D, Tiryaki A, Karagüzel E, Karahan C (2012) Nitric oxide and asymmetrical dimethylarginine levels in acute mania. Bulletin of Clinical Psychopharmacology 22:

https://doi.org/10.5455/bcp.20111212083708

Schneider CA, Rasband WS, Eliceiri KW (2012) NIH Image to ImageJ: 25 years of image analysis. Nature Methods 9: 671-675. https://doi.org/10.1038/nmeth.2089

Selley ML (2003) Increased concentrations of homocysteine and asymmetric dimethylarginine and decreased concentrations of nitric oxide in the plasma of patients with Alzheimer's disease. Neurobiol Aging 24: 903-7. https://doi.org/10.1016/s0197-4580(03)00007-1

Selley ML (2004) Increased (E)-4-hydroxy-2-nonenal and asymmetric dimethylarginine concentrations and decreased nitric oxide concentrations in the plasma of patients with major depression. Journal of Affective Disorders 80: 249-256. https://doi.org/10.1016/S0165-0327(03)00135-6

Son H, Hawkins RD, Martin K, Kiebler M, Huang PL, Fishman MC, Kandel ER (1996) Long-term potentiation is reduced in mice that are doubly mutant in endothelial and neuronal nitric oxide synthase. Cell 87: 1015-1023.

Sonar SA, Lal G (2019) The iNOS activity during an immune response controls the CNS pathology in experimental autoimmune encephalomyelitis. Frontiers in immunology 10: 710-710. https://doi.org/10.3389/fimmu.2019.00710

Stamatoyannopoulos JA, Snyder M, Hardison R, Ren B, Gingeras T, Gilbert DM, Groudine M, Bender M, Kaul R, Canfield T, et al (2012) An encyclopedia of mouse DNA elements (Mouse ENCODE). Genome Biology 13: 418. https://doi.org/10.1186/gb-2012-13-8-418

Suzuki-Yamamoto T, Ito A, Yokoro M, Suzuki M, Kimoto M (2012) Immunohistochemical localization of NNOS, PRMT and DDAH in the rat central nervous system. Nitric Oxide 27: S20.

https://doi.org/10.1016/j.niox.2012.04.070

The Human Brain (2020) The Human Brain Coronal Atlas.

http://www.thehumanbrain.info/head_brain/coronal.php March 12, 2020.

Todd AE, Orengo CA, Thornton JM (2001) Evolution of function in protein superfamilies, from a structural perspective11Edited by A. R. Fersht. Journal of Molecular Biology 307: 1113-1143. https://doi.org/10.1006/jmbi.2001.4513

Tomlinson JA, Caplin B, Boruc O, Bruce-Cobbold C, Cutillas P, Dormann D, Faull P, Grossman RC, Khadayate S, Mas VR, et al (2015) Reduced renal methylarginine metabolism protects against progressive kidney damage. J Am Soc Nephrol 26: 3045-59. https://doi.org/10.1681/asn.2014030280 
Toth J, Racz A, Kaminski PM, Wolin MS, Bagi Z, Koller A (2007) Asymmetrical Dimethylarginine Inhibits Shear Stress\&\#x2013;Induced Nitric Oxide Release and Dilation and Elicits Superoxide-Mediated Increase in Arteriolar Tone. Hypertension 49: 563-568. https://doi.org/doi:10.1161/01.HYP.0000256764.86208.3d

Tran CTL, Fox MF, Vallance P, Leiper JM (2000) Chromosomal localization, gene structure, and expression pattern of DDAH1: Comparison with DDAH2 and implications for evolutionary origins. Genomics 68: 101105. https://doi.org/10.1006/geno.2000.6262

Uhlén M, Fagerberg L, Hallström BM, Lindskog C, Oksvold P, Mardinoglu A, Sivertsson Å, Kampf C, Sjöstedt E, Asplund A, et al (2015) Tissue-based map of the human proteome. Science 347: 1260419. https://doi.org/10.1126/science.1260419

Ustundag MF, Ozcan H, Gencer AG, Yilmaz ED, Uğur K, Oral E, Bilici M (2020) Nitric oxide, asymmetric dimethylarginine, symmetric dimethylarginine and L-arginine levels in psychotic exacerbation of schizophrenia and bipolar disorder manic episode. Saudi Med J 41: 38-45.

https://doi.org/10.15537/smj.2020.1.24817

Usui M, Matsuoka H, Miyazaki H, Ueda S, Okuda S, Imaizumi T (1998) Increased endogenous nitric oxide synthase inhibitor in patients with congestive heart failure. Life Sci 62: 2425-30. https://doi.org/10.1016/s0024-3205(98)00225-2

Vallance P, Leone A, Calver A, Collier J, Moncada S (1992) Endogenous dimethylarginine as an inhibitor of nitric oxide synthesis. J Cardiovasc Pharmacol 20 Suppl 12: S60-2.

Wang D, Gill PS, Chabrashvili T, Onozato ML, Raggio J, Mendonca M, Dennehy K, Li M, Modlinger P, Leiper $\mathrm{J}$, et al (2007) Isoform-specific regulation by NG,NG-dimethylarginine dimethylaminohydrolase of rat serum asymmetric dimethylarginine and vascular endothelium-derived relaxing factor/NO. Circulation Research 101: 627-635. https://doi.org/10.1161/circresaha.107.158915

Wojciak-Stothard B, Torondel B, Tsang LY, Fleming I, Fisslthaler B, Leiper JM, Vallance P (2007) The ADMA/DDAH pathway is a critical regulator of endothelial cell motility. J Cell Sci 120: 929-42. https://doi.org/10.1242/jcs.002212

Zhou QG, Hu Y, Hua Y, Hu M, Luo CX, Han X, Zhu XJ, Wang B, Xu JS, Zhu DY (2007) Neuronal nitric oxide synthase contributes to chronic stress-induced depression by suppressing hippocampal neurogenesis. $J$ Neurochem 103: 1843-54. https://doi.org/10.1111/j.1471-4159.2007.04914.x

Zoccali C, Bode-Böger SM, Mallamaci F, Benedetto FA, Tripepi G, Malatino LS, Cataliotti A, Bellanuova I, Fermo I, Frölich JC, et al (2001) Plasma concentration of asymmetrical dimethylarginine and mortality in patients with end-stage renal disease: a prospective study. The Lancet 358: 2113-2117. https://doi.org/10.1016/S0140-6736(01)07217-8

\section{Table}


Table 1 List of used antibodies

\begin{tabular}{|c|c|c|c|}
\hline $\begin{array}{l}\text { Primary } \\
\text { antibodies }\end{array}$ & Hosts & Dilution & Identifier \\
\hline Anti-DDAH1 & Rabbit & $1: 500$ & PA5-52278 (ThermoFisher) \\
\hline Anti-DDAH1 & Mouse & $1: 500$ & $\begin{array}{l}\text { clone } 3 \mathrm{H} 10 \text { (Prof. Masumi Kimoto, Okayama } \\
\text { Prefectural University) }\end{array}$ \\
\hline Anti-DDAH1 & Rabbit & $1: 500$ & HPA006308 (MERCK) \\
\hline Anti-DDAH1 & Goat & $1: 10000$ & ab2231 (Abcam) \\
\hline Anti-DDAH2 & Rabbit & $1: 200$ & ab232694 (Abcam) \\
\hline Anti-DDAH2 & Goat & $1: 1000$ & ab1383 (Abcam) \\
\hline Anti-GFAP & Goat & $1: 1000$ & ab53554 (Abcam) \\
\hline Anti-NeuN & Mouse & $1: 1000$ & ab104224 (Abcam) \\
\hline Anti-Olig 2 & Rabbit & $1: 250$ & ab109186 (Abcam) \\
\hline Anti-Iba1 & Rabbit & $1: 1000$ & 019-19741 (Wako Chemicals) \\
\hline Anti-CD31 & Mouse & $1: 500$ & ab64543 (Abcam) \\
\hline $\begin{array}{l}\text { Secondary } \\
\text { antibodies }\end{array}$ & Host & Dilution & Company \\
\hline $\begin{array}{l}\text { Anti-rabbit Alexa } \\
488\end{array}$ & Goat & $1: 1000$ & ab150117 (Abcam) \\
\hline $\begin{array}{l}\text { Anti-rabbit Alexa } \\
648\end{array}$ & Donkey & $1: 1000$ & ab150067 (Abcam) \\
\hline $\begin{array}{l}\text { Anti-mouse Alexa } \\
568\end{array}$ & Goat & $1: 1000$ & ab175701 (Abcam) \\
\hline $\begin{array}{l}\text { Anti-goat Alexa } \\
488\end{array}$ & Donkey & $1: 1000$ & ab150133 (Abcam) \\
\hline
\end{tabular}


Figures

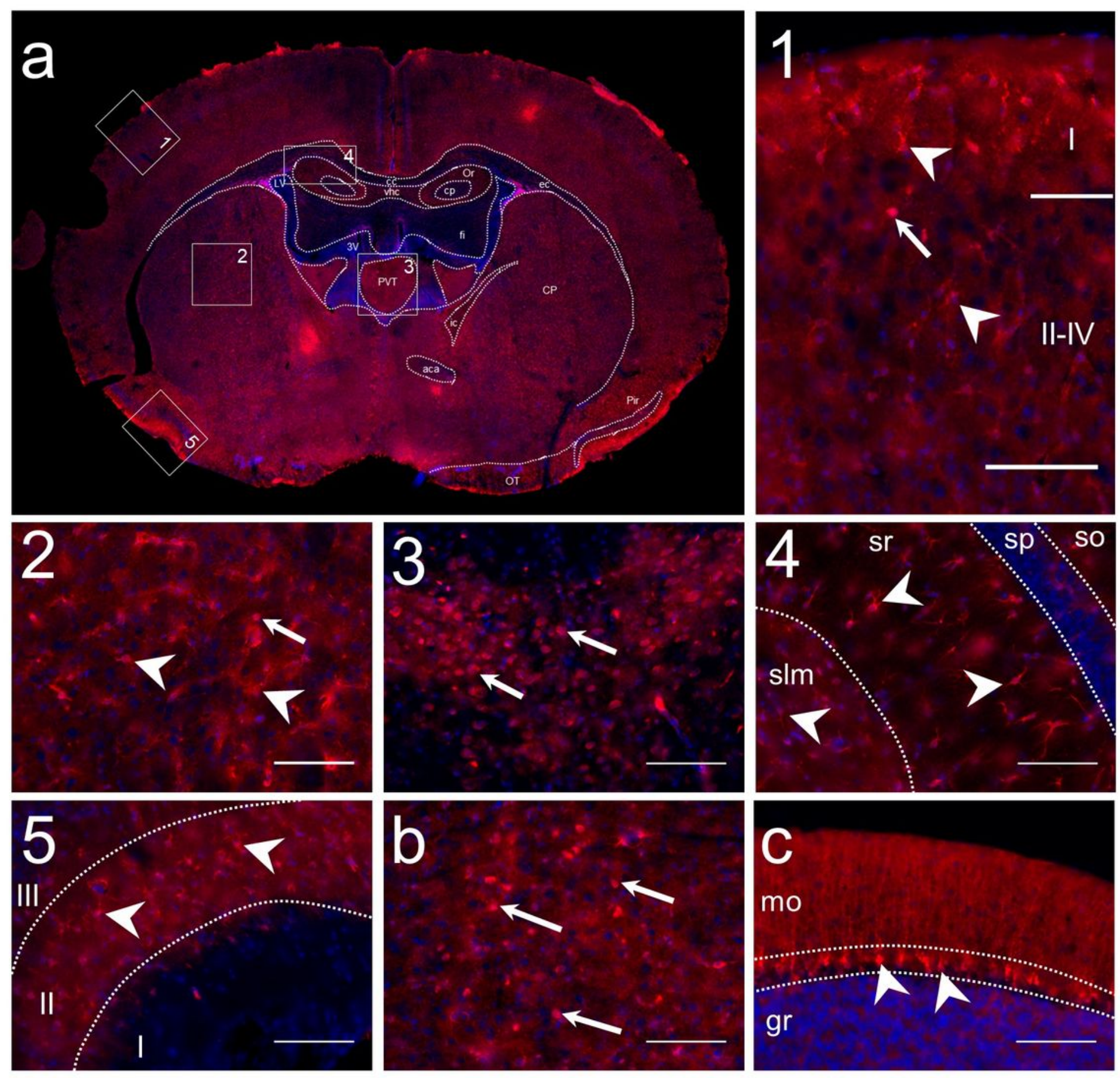

Figure 1 
DDAH1 is widely distributed in the mouse brain. To assess patterns of DDAH1 protein expression, coronal mouse brain sections were stained with anti-DDAH1 antibody. a Representative section from Bregma -0.94. Regions with intense DDAH1 expression include: 1. DDAH1 positive cells in the cortex in all layers I and II-IV; 2. Intense DDAH1 expression in caudoputamen (CP); 3. DDAH1 positive cells in the paraventricular nucleus of the thalamus (PVT) appear in a round shape; 4. DDAH1 cells are present in $\mathrm{HPF}$, in stratum oriens (so), stratum radialis (sr) and in stratum lacunosum-moleculare (slm), but not in pyramidal layer (sp); 5. DDAH1 immunoreactivity in the layer II in the piriform cortex. b DDAH1 positive cells in dorsal raphe. c DDAH1 positive cells specific to Purkinje layer of cerebellum; mo - molecular layer, gr - granular layer. Nuclear staining in blue with DAPI. White arrows and arrowheads indicate DDAH1 immunoreactive cells with differing morphology. Scale bars $100 \mu \mathrm{m}$ 


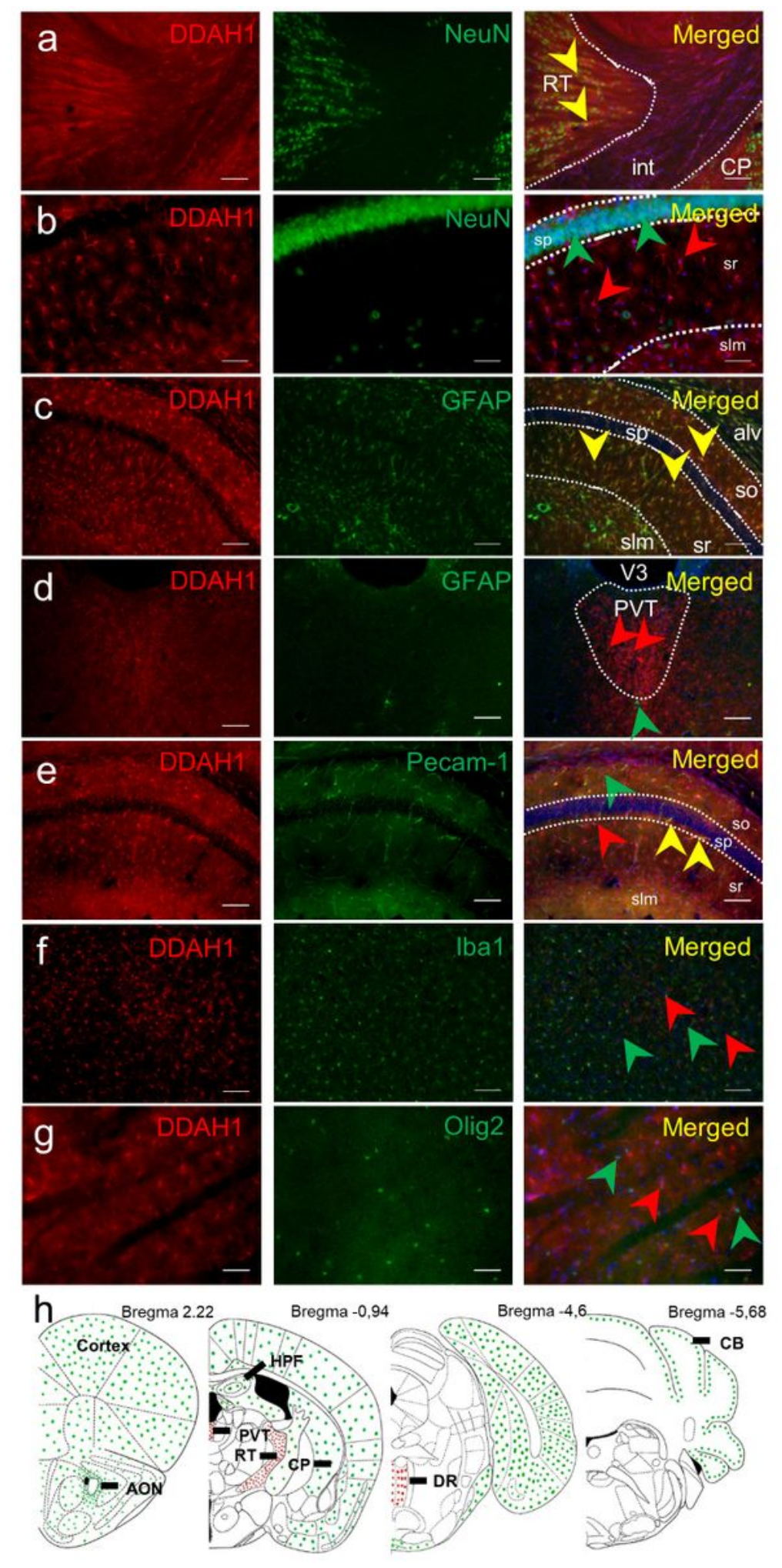

Figure 2

DDAH1 expression in different cell types. Mouse brain sections were stained with anti-DDAH1 antibody (red, first column) and main cell markers: neuronal marker (NeuN), glial fibrillary acidic protein (GFAP), oligodendrocyte transcription factor (Olig2), ionized calcium-binding adapter molecule 1 (Iba1), platelet/endothelial cell adhesion molecule 1 (PECAM-1), (green, second column). a Co-staining DDAH1 and NeuN in the RT; int - internal capsule. b DDAH1 signal in the HPF did not overlap with NeuN but 
showed complete overlap with GFAP in all hippocampal layers and with some cells in white matter of alveus c. $d$ No overlap of staining of DDAH1 and GFAP in PVT. e Co-labelling of DDAH1 and PECAM-1 is observed in vessels in the HPF. $f$ Striatal example of staining with DDAH1 and Iba1, no overlay between these proteins was observed. g Similarly, no overlap between DDAH1 and Olig2 was observed. h Overview scheme summarizing DDAH1/NeuN positive cells (red dots) and DDAH1/GFAP positive cells (green dots) and their correspondence to brain structures: cortex, anterior olfactory nucleus (AON); caudoputamen (CP); hippocampal formation (HPF); reticular nucleus of the thalamus (RT); paraventricular nucleus of the thalamus (PVT); dorsal Raphe (DR); cerebellum (CB); stratum oriens (so); stratum radialis (sr); stratum lacunosum-moleculare (slm); single cells in pyramidal layer (sp); alveus (alv); 3d ventricle (V3). Nuclei staining in blue with DAPI. Yellow arrows mark overlaps between cell marker (green) and DDAH1+ cells (red). Scale bar is $100 \mu \mathrm{m}$
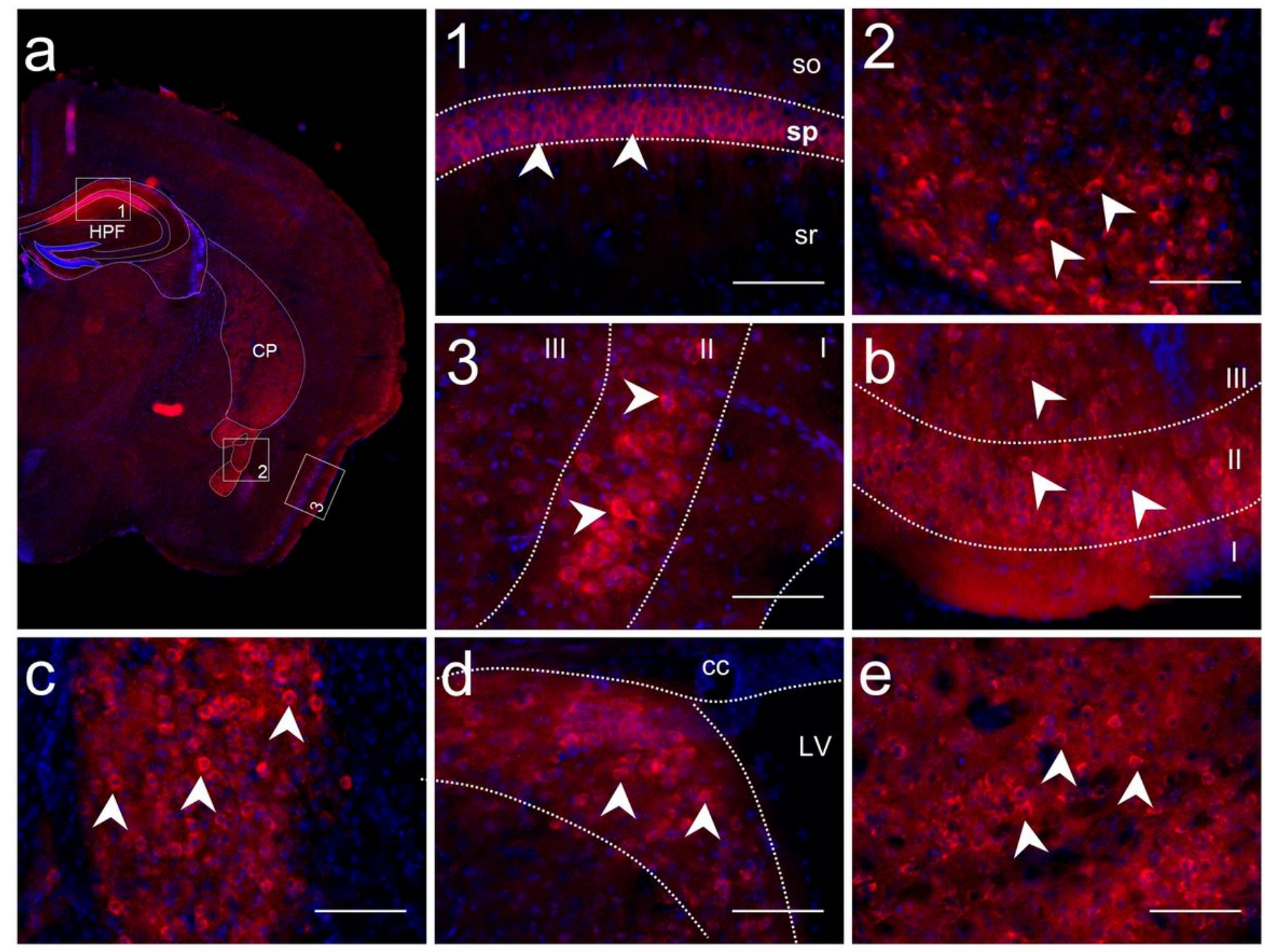

\section{Figure 3}

Immunohistological analysis of mouse brain sections revealed a limited number of regions with DDAH2 expression. To assess patterns of DDAH2 expression, mouse brain sections were stained with antiDDAH2 antibody. a Overview of coronal sections with regions of intense DDAH2 expression: 1. DDAH2 
positive cells in pyramidal layer (sp) of CA1 in the hippocampal formation but not in stratum oriens (so), stratum radialis (sr); 2. DDAH2 positive cells in the central amygdalar nuclei (CEA); 3. DDAH2 immunoreactivity in the layer II in the piriform cortex. b DDAH2 expression in the II and III layer of the olfactory tubercule. c DDAH2 positive cells in the bed nuclei of the stria terminalis. $d$ DDAH2 positive cells in the lateral septal nucleus; LV - lateral ventricle, cc - corpus callosum. e Intense DDAH2 expression in the fundus of the striatum. Nuclear staining in blue with DAPI. White arrows indicate DDAH2 immunoreactivity. Scale bar is $100 \mu \mathrm{m}$
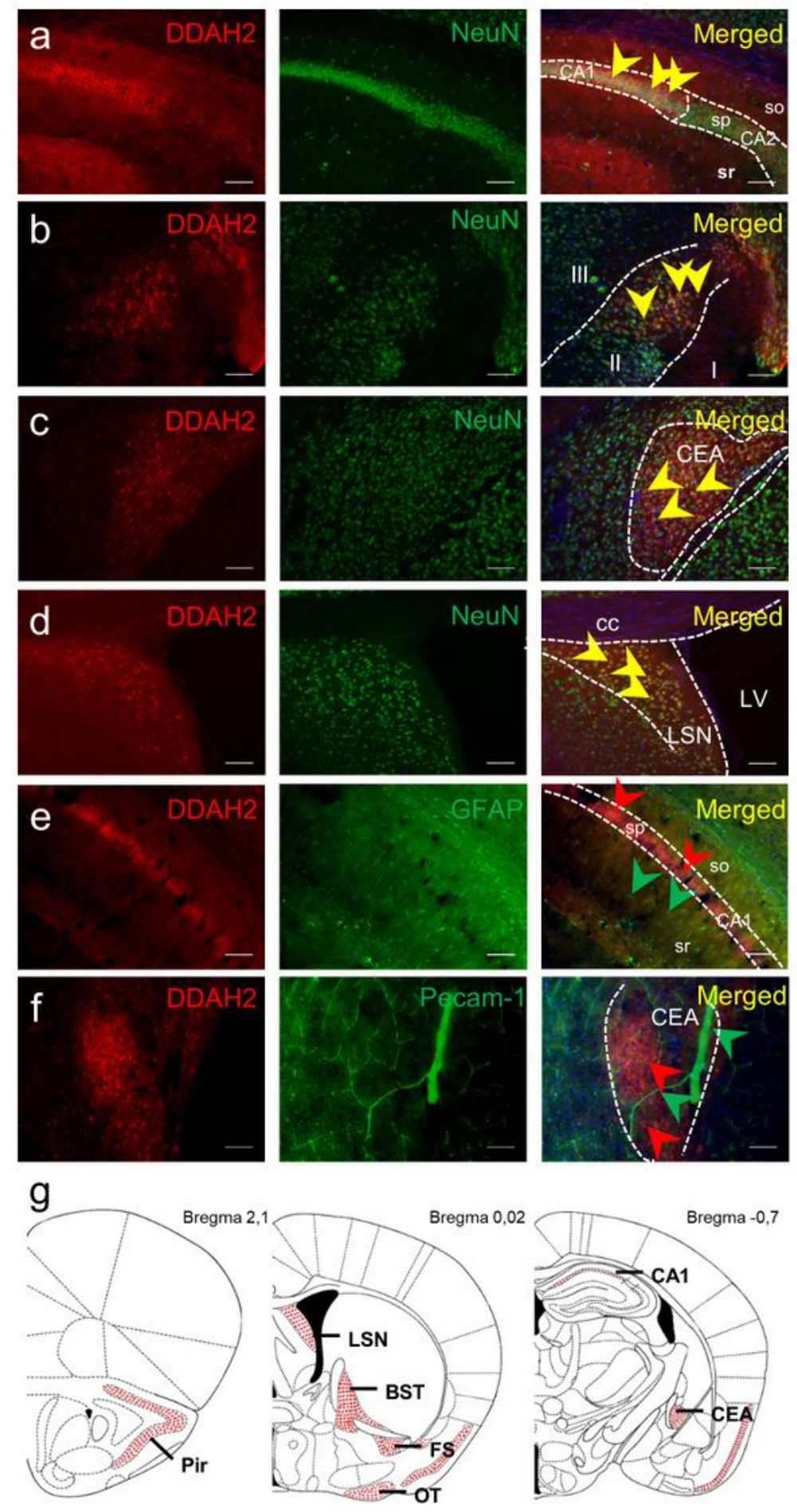


\section{Figure 4}

DDAH2 is expressed in neuronal cells. Mouse brain sections were co-stained with anti-DDAH2 (red, first column) and anti-neuronal marker (NeuN) antibodies (green, second column). a DDAH2/NeuN positive cells in the pyramidal layer (sp) of CA1, but not stratum oriens (so), stratum radialis (sr) and sp of CA2. b DDAH2/NeuN positive cells in layer II, but not layers I and III in piriform cortex. c Staining of the CEA shows DDAH2/NeuN co-localization d DDAH2/NeuN co-localization in lateral septal nucleus; cc - corpus callosum, LV - lateral ventricle. e No overlap of staining of DDAH2 and GFAP in HPF. $f$ No overlap of staining of DDAH2 and PECAM- 1 in CEA. g Overview scheme summarizing, DDAH2/NeuN positive cells (red dots) in piriform cortex (Pir); fundus of striatum (FS); bed nuclei of stria terminalis (BST); olfactory tubercle (OT); central amygdalar nucleus (CEA); Ammon's horn (CA1); lateral septal nucleus (LSN). Nuclear staining in blue with DAPI. Yellow arrows mark overlap. Scale bar is $100 \mu \mathrm{m}$ 


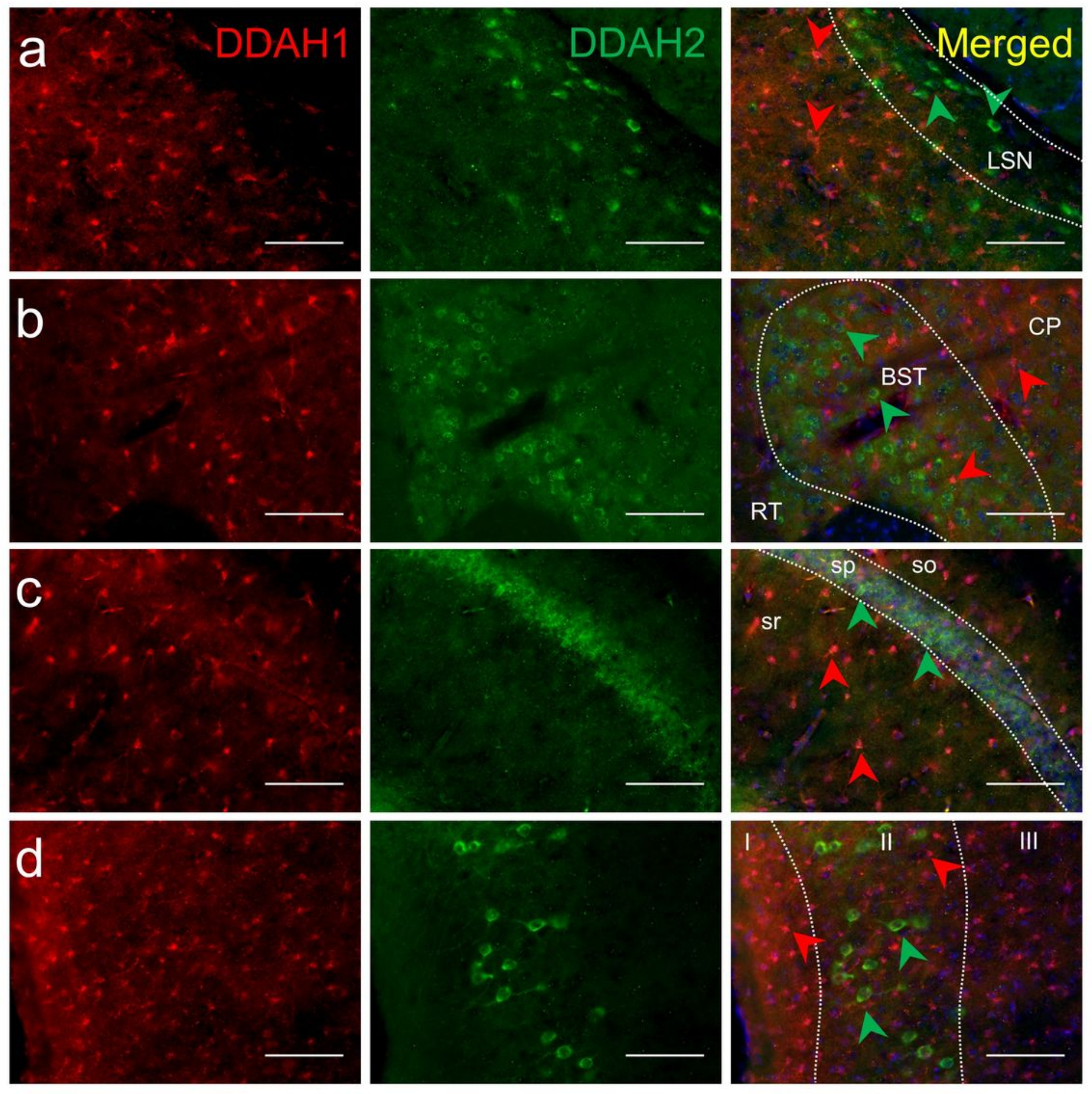

\section{Figure 5}

DDAH1 and DDAH2 do not overlap. Sagittal mouse brain sections were stained with anti-DDAH1 (red, first column) and anti-DDAH2 (green, second column). a DDAH1 and DDAH2 are both expressed in the lateral septal nucleus (LSN) but in different cells. Additionally, DDAH1 is found in caudoputamen (CP). b DDAH2 immunoreactivity was intense in bed nuclei of stria terminalis (BST). Here, DDAH1 cells were smaller and did not overlap with DDAH2. RT - reticular nucleus of the thalamus. c Neurons of pyramidal layer of CA1 
of hippocampal formation (HPF) expressed DDAH2 but not DDAH1, which was present in glial cells of HPF. Sp - pyramidal layer; so - stratum oriens; sr - stratum radialis. d DDAH2 is expressed in large round cells in layer II of the entorhinal cortex, while DDAH1 positive cells were smaller and observed in all layers. Red arrows - DDAH1 positive cells, green arrows - DDAH2 positive cells. Scale bar is $100 \mu \mathrm{m}$

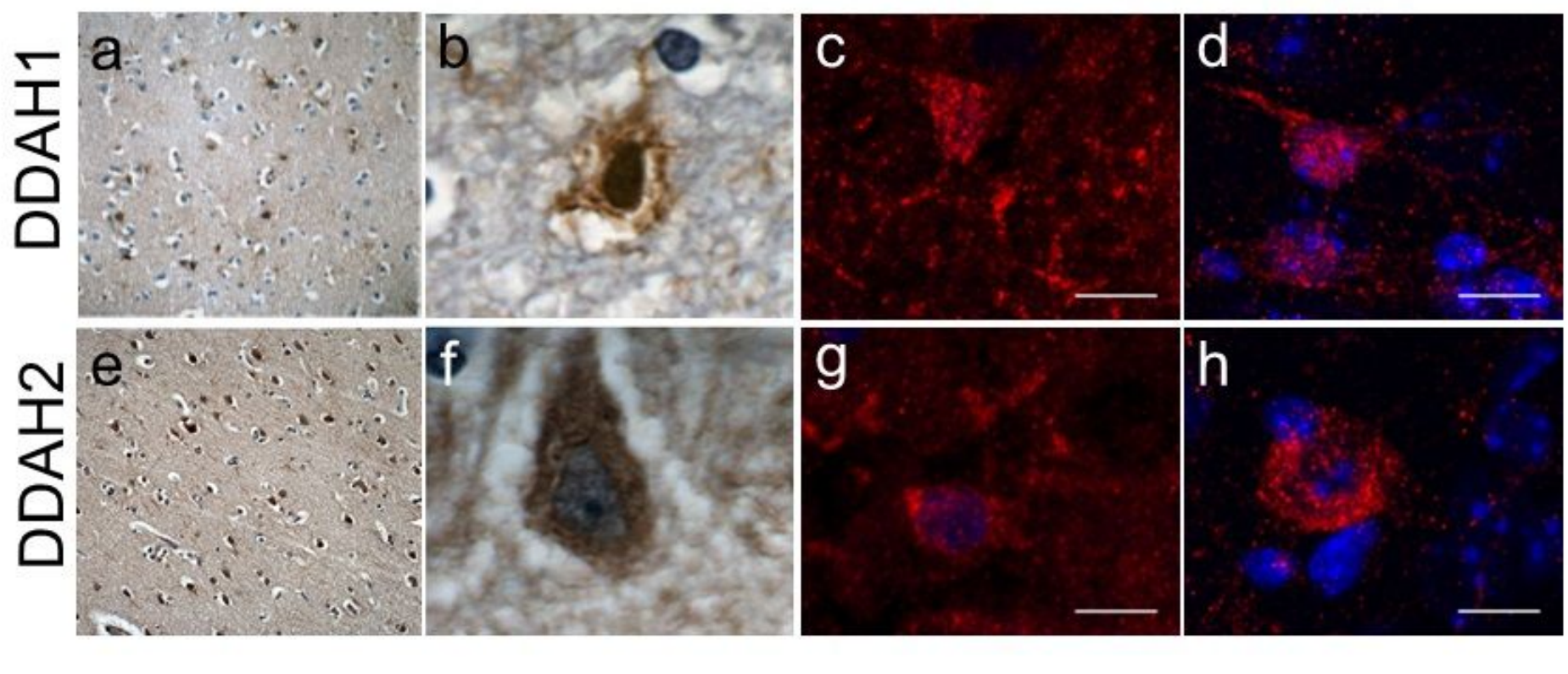

Figure 6

DDAH1 and DDAH2 are expressed by phenotypically similar cells in mouse and human brain tissue. Expression of DDAH1 and DDAH2 was compared in mouse and human brain tissue. Both DDAH1 a and DDAH2 e expression was observed in human medial frontal gyrus tissue with different morphological characteristics. While DDAH1 expression resembles astrocytes $b$, strong DDAH2 expression is observed in neurons $\mathrm{f}$. Cortical DDAH1 positive cells have small soma and multiple processes in human $\mathrm{b}$ and murine samples c,d. Amygdala DDAH2 immunoreactivity is observed in both human $f$ and mouse g,h. a,e 20x, b,f $100 x, c, d, g, h$. Scale bar is $10 \mu \mathrm{m}$

\section{Supplementary Files}

This is a list of supplementary files associated with this preprint. Click to download.

- SupplementaryMaterialsandFigures.pdf

- TableS1.xIsx

- TableS2.xIsx

- TableS3.xIsx 
- Tables4.xIsx

Page 28/28 